\title{
Regulation of Osmotic Balance and Increased Antioxidant Activities under Heat Stress in Abelmoschus esculentus L. Triggered by Exogenous Proline Application
}

\author{
Rashid Hussain 1,2, Choudhary Muhammad Ayyub ${ }^{1}$, Muhammad Rashid Shaheen ${ }^{2}$, Sahar Rashid ${ }^{3}$, \\ Muhammad Nafees ${ }^{2}$, Saif Ali ${ }^{4}$, Madiha Butt ${ }^{5}$, Mujahid Ali ${ }^{6}$, Ambreen Maqsood ${ }^{7}$ (D), Sajid Fiaz ${ }^{8}$ (D), \\ Sunny Ahmar ${ }^{9}$, Tahir Mahmood ${ }^{10}$ and Freddy Mora-Poblete ${ }^{9, * \text { CD }}$
}

check for updates

Citation: Hussain, R.; Ayyub, C.M.; Shaheen, M.R.; Rashid, S.; Nafees, M. Ali, S.; Butt, M.; Ali, M.; Maqsood, A.; Fiaz, S.; et al. Regulation of Osmotic Balance and Increased Antioxidant Activities under Heat Stress in Abelmoschus esculentus L. Triggered by Exogenous Proline Application. Agronomy 2021, 11, 685. https:// doi.org/10.3390/agronomy11040685

Academic Editors: Raju Soolanayakanahally and M. S. Sheshshayee

Received: 23 January 2021

Accepted: 1 April 2021

Published: 3 April 2021

Publisher's Note: MDPI stays neutral with regard to jurisdictional claims in published maps and institutional affiliations.

Copyright: (C) 2021 by the authors. Licensee MDPI, Basel, Switzerland. This article is an open access article distributed under the terms and conditions of the Creative Commons Attribution (CC BY) license (https:// creativecommons.org/licenses/by/ $4.0 /)$.
1 Institute of Horticultural Sciences, University of Agriculture, Faisalabad 38040, Punjab, Pakistan; rashiduaf1947@gmail.com (R.H.); cmayyub91@yahoo.com (C.M.A.)

2 Department of Horticultural Sciences, Faculty of Agriculture and Environment, The Islamia University of Bahawalpur, Bahawalpur 63100, Punjab, Pakistan; rashid.shaheen@iub.edu.pk (M.R.S.); muhammad.nafees@iub.edu.pk (M.N.)

3 Horticultural Research Institute, Ayub Agricultural Research Institute, Faisalabad 38040, Punjab, Pakistan; sahar_rasheed25@yahoo.com

4 College of Agriculture, Nanjing Agricultural University, Nanjing 210000, China; drsaifbhatti@webmail.hzau.edu.cn

5 College of Agriculture, Bahauddin Zakariya University, Bahadur Sub-Campus Layyah, Layyah 31200, Punjab, Pakistan; madihab99@gmail.com

6 Department of Horticulture, University College of Agriculture, University of Sargodha, Sargodha 40100, Pakistan; mujahidali2263@gmail.com

7 Department of Plant Pathology, Faculty of Agriculture and Environment, The Islamia University of Bahawalpur, Bahawalpur 63100, Punjab, Pakistan; ambreenagrarian@gmail.com

8 Department of Plant Breeding and Genetics, The University of Haripur, Haripur 22600, kpk, Pakistan; sfiaz@uoh.edu.pk

9 Institute of Biological Sciences, University of Talca, 1 Poniente 1141, Talca 3460000, Chile; sunny.ahmar13@gmail.com

10 Molecular Plant Breeding Laboratory, Department of Plant Breeding and Genetics, Pir Mehar Ali Shah Arid Agriculture University, Rawalpindi 46000, Punjab, Pakistan; tahirmtaha@hotmail.com

* Correspondence: morapoblete@gmail.com

\begin{abstract}
Keeping in view the yield losses instigated by heat stress in several crops, we carried out an experiment to explore the curative effect of exogenous applications of proline on the morphophysiological, biochemical, and water-related attributes of okra genotypes under high-temperature stress (controlled conditions). Four contrasting genotypes $\mathrm{C} 1, \mathrm{C} 2, \mathrm{C} 3$, and $\mathrm{C} 4$ heat tolerant and heat sensitive genotypes were selected from a diverse panel of okra genotypes $(n=100)$ to examine plant responses to high-temperature stress and exogenous application of proline. Four-week-old seedlings were subjected to heat stress by gradually increasing the temperature of a growth chamber from $28 / 22{ }^{\circ} \mathrm{C}$ to $45 / 35^{\circ} \mathrm{C}$ (day/night) and sprayed with an optimized proline concentration $2.5 \mathrm{mM}$. The experiment consisted of a factorial arrangement of treatments in a completely randomized design. The results showed that there were maximum increases in shoot length (32.7\%), root length (58.9\%), and shoot fresh (85.7\%). The quantities of leaves per plant were increased by $52.9 \%, 123.6 \%, 82.5 \%$, and $62.2 \%$ in $\mathrm{C} 1, \mathrm{C} 2, \mathrm{C} 3$, and $\mathrm{C} 4$ after proline application. On the other hand, only root fresh weight decreased in all genotypes after proline application by $23.1 \%, 20 \%, 266.7 \%$, and $280.8 \%(C 1, C 2, C 3$, C4). A lower leaf temperature of $27.72{ }^{\circ} \mathrm{C}$, minimum transpiration of $3.29 \mathrm{mmol} \mathrm{m}^{-2} \mathrm{~s}^{-1}$, maximum photosynthesis of $3.91 \mu \mathrm{mol} \mathrm{m}^{-2} \mathrm{~s}^{-1}$, and a maximum water use efficiency of $1.20 \mu \mathrm{mol} \mathrm{CO} \mathrm{mmol}$ $\mathrm{H}_{2} \mathrm{O}$ were recorded in the genotypes $\mathrm{C} 2, \mathrm{C} 1, \mathrm{C} 3$, and $\mathrm{C} 4$, respectively. The highest enzymatic activity of superoxide dismutase, peroxidase and catalase were 14.88, 0.31, and $0.15 \mathrm{U}$ mg-protein in $\mathrm{C} 2, \mathrm{C} 1$, and $\mathrm{C} 3$, respectively. Maximum leaf proline, glycinebetaine, total free amino acids, and chlorophyll content $3.46 \mathrm{mg} \mathrm{g}^{-1}, 4.02 \mathrm{mg} \mathrm{g}^{-1}, 3.46 \mathrm{mg} \mathrm{g}^{-1}$, and 46.89 (in C2), respectively, due to foliar applications of proline. Another important finding was that heat tolerance in okra was highly
\end{abstract}


linked highly linked to genotypes' genetic potential, having more water use efficiency, enzymatic activities, and physio-biochemical attributes under the foliar applications of proline.

Keywords: climate change; gas exchange; heat stress; okra; physiology; proline; water relations

\section{Introduction}

Climate change is a great threat to the food security of the globe. It has been observed that there were increases of $0.85^{\circ} \mathrm{C}$ and $0.6 \pm 2{ }^{\circ} \mathrm{C}$ in the average temperature of the surface of the globe over the past two centuries [1,2]. It is predicted that there will be an increase of $1-3{ }^{\circ} \mathrm{C}[3]$ or $1.4-5.8^{\circ} \mathrm{C}$ [4] by the 21 st century. It has been discussed that this temperature rise will be beneficial for crop production in the cooler part of the world, but it is dangerous for crop production in the warmer or low laying areas [1,5]. High-temperature stress leads to drought stress, and a combination of both these stresses give birth to a third stress, namely salt stress or soil salinization. All of this stress ultimately causes crop production losses, imposing food shortage for future generations [6,7]. Climate change and abiotic stresses cause great damage to the agriculture production [8]; in some cases, it has been reported at up to 50\% [9] and even 51-82\% [10]. Each degree rise in seasonal temperature cause a crop loss of $17 \%[2,9]$. Sessile plants are exposed to an array of extreme climates, including seasonal, daily, and hourly. Every plant species has its optimum ranges for seasonal temperature from seed germination to reproduction [6]. Variation in the temperature causes severe damage to the plant starting from morphological damages, i.e., leaf and twig scorching, burning of stems, branches, and leaves, leaf abscission and senescence, root shoot growth inhibition, discoloration, and damage to fruits, and ultimately a lower yield [2,11]. At the intracellular level, high temperature affects macromolecules and substructures of the plant cell [1]. When plants are exposed to high temperature, at the anatomical level, there is a reduction in cell size, stomatal closure, excessive water loss, and increases in trachomatous and stomatal densities [12]. Leaf gaseous exchange properties are halted at high temperature, while the plant is in a vegetative phase and experiencing flower bud abortion at the reproductive phase $[13,14]$. High temperature also affects plant physiological mechanisms. During heat stress, there is reduced water potential of the leaf [12], increased transpiration rate, water loss, and many physiological processes halt [15]. The photosynthesis rate of the canopy rapidly decreases at an extreme temperature [1,16]. Transpiration and evaporation rate are accelerated at a high temperature and causes water loss [17]. Heat stress causes damage to every step of plant life, starting from seed sowing to crop production and yield.

As a defensive mechanism under heat stress, the plant produces compounds of organic nature that are lower in molecular weight and referred to as compatible solutes, or osmolytes, and accumulate them in their bodies at cellular levels [13,18]. Examples of these compatible solutes are proline, sugars, tertiary sulphonium, quaternary ammonium, glycinebetaine, and sugar alcohols [19]. These enhance the tolerance potential of plants against heat stress. Glycinebetaine and proline naturally accumulate in plants under stress conditions, which have been observed, for instance, in maize [20] and sugarcane [11].

The accumulation of osmoprotectants, such as L-proline, is an important mechanism by which plants can smother reactive oxygen species (ROS) to cope with high temperatureinduced oxidative stress [21]. Proline is an amino acid known to be associated with oxidative stress responses, given that it preserves protein composition from defiling by extinguishing hydroxyl radicals and can neutralize cell membrane through phospholipid synergy; it can also be utilized as the fountainhead of energy and nitrogen [22]. Proline helps to keep a fully utilitarian photosynthetic paraphernalia due to its potential to sustain complex II within the electron transport chain and proteins and enzymes such as rubisco [23]. Moreover, Ben Ahmed et al. [24] found that foliar proline application attenuates reductions in plants' overall photosynthetic activity under salinity stress. Endogenic 
L-proline concentrations are usually elevated under oxidative stress to counter the amassing of ROS, thus safeguarding enzymes and other molecules from oxidation. Proline has been applied directly to the crop's foliage or via fertigation for root immersion. In fact, exogenous L-proline has been exhibited to douse ROS produced by heat, saline, and heavy metal-induced stress; as an outcome, cell turgidity was sustained, and photosynthetic activity was conserved [25]. The biosynthesis and build-up of osmoprotectants in plants is a subservient energy process, whereas the exogenous proline application could potentially surge proline in the cell without the undesired use of energy for metabolism [21].

There are many approaches to induce heat tolerance in plants, which include conventional breeding, genetic manipulation, and biotechnological methods. These are long-term approaches that require years to achieve an outcome. In this sense, a short-term approach is needed along with these long-term approaches, as there are huge losses in crop production due to heat stress, a great threat to food security worldwide. Among short-term approaches to inducing heat tolerance in plants, osmolytes' foliar application seems to be one of the best strategies [13]. In this study, we hypothesized that exogeneous proline application may improve the osmotic balance and can increase antioxidant activities in Abelmoschus esculentus L. under heat stress treatment. Therefore, keeping in view the several crop losses caused by high-temperature stress, we performed an experiment designed to explore the curative effect of proline in plants exposed to heat stress on morphological, physiological, biochemical, and water-related attributes of okra contrasting genotypes under controlled environmental conditions. This study aimed to confirm the enhancement of okra's heat stress tolerance potential through proline's exogenous application.

\section{Materials and Methods}

\subsection{Plant Material and Growing Conditions}

The study was conducted in growth chambers fully automated for temperature, light (day and night hours), and relative humidity located in the mushroom lab in the Institute of Horticultural Sciences, University of Agriculture, Faisalabad. Four contrasting genotypes, two heat-tolerant $(\mathrm{C} 1=$ VI051062 and C2 = VI060131) and two heat-sensitive (C3 = VI046554 and C4 = VI048594), were selected based on morphological differences (shoot length, root length, number of leaves, etc.) and physiological attributes (photosynthesis, transpiration, leaf temperature, etc.) from a panel consisting of a diverse set of okra genotypes $(n=100$, from the World Vegetable Center, Taiwan) [26]. Four seeds of these genotypes were sown in $9 \mathrm{~L}$ plastic pots and soaked overnight in water. Sand was used as a growth medium, and half-strength Hoagland's solution was used with irrigation water as a nutrient medium. Hoagland's solution was added weekly and water was added when and often required. After germination, four plants per pot were maintained and replicated four times. Temperature was set at $28 / 22{ }^{\circ} \mathrm{C}$ (day/night) in a controlled environmental chamber, with relative humidity set to $85 / 95 \%$ (day/night), and light intensity to 43,300 lux. Day and night hours were set to $14 \mathrm{~h}$ of the day and $10 \mathrm{~h}$ of the night.

\subsection{Heat Treatment}

Four weeks after germination, temperature was raised to $45 / 35^{\circ} \mathrm{C}$ (day/night) by increasing $2{ }^{\circ} \mathrm{C} /$ day to prevent the plants from osmotic shock. It took $17 / 13$ (day/night) days to reach a specified temperature. Plants were kept at $45 / 35^{\circ} \mathrm{C}$ (day/night) for seven days. Heat treatment was applied to both treatments (proline-free and with proline) and all genotypes.

\subsection{Exogenous Application of Proline}

A previously optimized dose of $2.5 \mathrm{mM}$ of proline was sprayed [27], and plants were kept under heat stress conditions $\left(45 / 35^{\circ} \mathrm{C}\right.$ (day/night)) after proline application. Seven days after proline application, data were recorded for the following attributes at the seedling stage. 


\subsection{Morphological Attributes}

At the end of the experiment, morphological attributes such as shoot length, root length, shoot, and root fresh weight, shoot and root dry weight, and the number of leaves per plant were recorded. Three plants from each replication were uprooted and washed with distilled water to remove adhering sand. Plants were wrapped with filter paper to remove any drop of water. Roots and shoots were then separated by cutting the stem base. Shoot and root length for three plants in each replication were measured with a meter rod in centimeters $(\mathrm{cm})$, and the average was calculated. Shoot and root fresh weight $(\mathrm{g})$ was recorded separately with a digital weighing balance. The same samples were used for the determination of dry weights. For dry weight, samples were placed in an oven (Memmert-110, Schwabach, Germany) and were dried at $70{ }^{\circ} \mathrm{C}$ for $72 \mathrm{~h}$. Dry weights were measured in grams by using a digital weighing balance. The number of leaves was counted for three plants in each replication, and the average was calculated.

\subsection{Physiological Attributes}

Physiological attributes were measured at principal growth stage 1 (15) [28]. For measurement of physiological attributes, such as photosynthetic rate $\left(\mu \mathrm{mol} \mathrm{CO} \mathrm{Cm}^{-2} \mathrm{~s}^{-1}\right)$, transpiration rate $\left(\mathrm{mmol} \mathrm{H}_{2} \mathrm{O} \mathrm{m}^{-2} \mathrm{~s}^{-1}\right)$, sub-stomatal $\mathrm{CO}_{2}(\mathrm{VPM})$, stomatal conductance to water ( $\mathrm{mmol} \mathrm{H}_{2} \mathrm{O} \mathrm{m}^{-2} \mathrm{~s}^{-1}$ ), and leaf temperature $\left({ }^{\circ} \mathrm{C}\right)$, three young fully developed/expanded and healthy leaves plant ${ }^{-1}$ (two plants in each replication treatment ${ }^{-1}$ ) were selected. These selected leaves were placed one by one in the chamber of a portable apparatus called an Infra-Red Gas Analyzer (IRGA) (LCi-SD, ADC Bio-scientific, UK). All readings of the above-mentioned physiological attributes were taken from 10:00 a.m. to 12:00 a.m. Water use efficiency ( $\mu \mathrm{mol} \mathrm{CO}_{2} \mathrm{mmol} \mathrm{H}_{2} \mathrm{O}$ was calculated using the following formula:

$$
\text { Water use efficiency }=\frac{\text { Photosynthetic rate }}{\text { Transpirational rate }} \text {. }
$$

\subsection{Antioxidant Enzyme Activity}

The activity of antioxidant enzymes superoxide dismutase (SOD), peroxidase (POD), and catalase (CAT) were measured. The activity of SOD was analyzed according to the protocol of Giannopolitis and Ries [29] by calculating its potential to hinder the photo reduction of nitroblue tetrazolium (NBT). The reaction solution $(3 \mathrm{~mL})$ contained $50 \mathrm{mM}$ NBT, $1.3 \mathrm{mM}$ riboflavin, $13 \mathrm{mM}$ methionine, $75 \mathrm{mM}$ EDTA, $50 \mathrm{mM}$ phosphate buffer ( $\mathrm{pH} 7.8$ ) and $20-50 \mathrm{~mL}$ of enzyme extract. The test tubes having the reaction solution were irradiated under light (15 fluorescent lamps) at $78 \mathrm{mmol} \mathrm{m}^{-2} \mathrm{~s}^{-1}$ for $15 \mathrm{~min}$. The absorbance of the irradiated solution was noted at $560 \mathrm{~nm}$ using a Spectrophotometer (Hitachi-650, Japan). One unit of SOD activity was explained as the amount of enzyme that restrained $50 \%$ of NBT photo decline.

The peroxidase (POD) and catalase (CAT) activities were measured by the procedure of [30] with some modification. The POD reaction solution $(3 \mathrm{~mL})$ comprised of $50 \mathrm{mM}$ phosphate buffer ( $\mathrm{pH} 5.0$ ), $20 \mathrm{mM}$ guaiacol, $40 \mathrm{mM} \mathrm{H}_{2} \mathrm{O}_{2}$ and $0.1 \mathrm{~mL}$ of enzyme extract. Variations in absorbance of the reaction solution at $470 \mathrm{~nm}$ were performed every $20 \mathrm{~s}$. One unit POD activity was assigned as an absorbance change of 0.01 units per min. The activity of each enzyme was expressed based on protein content. The CAT reaction solution $(3 \mathrm{~mL})$ was comprised of $50 \mathrm{mM}$ phosphate buffer ( $\mathrm{pH} 7.0), 5.9 \mathrm{mM} \mathrm{H}_{2} \mathrm{O}_{2}$, and $0.1 \mathrm{~mL}$ of enzyme extract. Changes in absorbance of the reaction solution were recorded after every 20 at $240 \mathrm{~nm}$. One unit CAT activity was specified as an absorbance change of 0.01 units per min. For the analysis of antioxidant enzyme activity and biochemical analysis, four samples per treatments were used, and each sample was composed by a mixture of four replications. 


\subsection{Water Relations}

2.7.1. Leaf Water Potential ( $\Psi$ w) (-MPa)

At the end of the experiment, a razor was used to cut the fully expanded three leaves from one plant per replication and was placed in the gasket of the pressure chamber (Model, 615 , USA) to compute leaf water potential $(\Psi w)$. The data were computed in the early in the morning.

\subsubsection{Leaf Osmotic Potential ( $\Psi \mathrm{s})$ (-MPa) by Osmometer}

The same leaf used in the pressure chamber for $\mathrm{Yw}_{\mathrm{w}}$ was placed in a plastic bag and kept at a low temperature $\left(-20{ }^{\circ} \mathrm{C}\right)$ in a freezer for a week. The frozen leaf material was then thawed at room temperature for half an hour, and cell sap was extracted with the help of a disposable syringe. An amount of $10 \mu \mathrm{L}$ of the extracted sap was placed on an osmometer (Wescor, Model-5500, USA) with the help of a plastic syringe, and $\Psi$ s measurement was taken.

\subsubsection{Leaf Turgor Potential $(\Psi \mathrm{p})=(\Psi \mathrm{w})-(\Psi \mathrm{s})(\mathrm{MPa})$}

Turgor potential ( $\Psi$ p) signifies the difference between $\Psi \mathrm{w}$ and $\Psi$ s, so $\Psi$ p was calculated, following the equation mentioned below:

$$
\Psi \mathrm{p}=\Psi \mathrm{w}-\Psi \mathrm{s}
$$

\subsubsection{Leaf Relative Water Content (RWC)}

Three mature leaves were detached randomly from 10 plants ( 2 from each replication per treatment). After tagging, leaves were washed under tap water for at least 5 min and then blotted with tissue paper. After blotting, the leaves were weighed and dipped in tap water for $24 \mathrm{~h}$, and their turgid weight was taken. After measuring the turgid weight, leaves were oven-dried at $72{ }^{\circ} \mathrm{C}$ for $48 \mathrm{~h}$, and their dry weight was measured with the help of a digital electrical balance (Bosch AE-160, Germany). The method reported by Weatherley and Barrs [31] was used to calculate the average RWC per replicate.

\subsection{Biochemical Attributes}

Chlorophyll content was measured using a chlorophyll meter (CCM-200plus BioScientific, USA). Proline content was calculated according to the method of Bates [32]. Glycinebetaine was estimated by the procedure of Grieve and Grattan [33]. Total free amino acids were estimated using the protocol of Biology [34].

\subsection{Experimental Design and Statistical Analysis}

The experiment consisted of a factorial arrangement (two factors) of treatments in a completely randomized design under controlled conditions. Collected data were subjected to statistical analysis by using Fisher's analysis of variance technique, and the significance of treatments was assayed using HSD (Tukey Test). Statistical analyses, including estimates of phenotypic correlation coefficient, were carried out using Statistics 8.1, USA. Sigma plot was used for regression analysis and graphical presentation of data.

\section{Results}

\subsection{Morphological Attributes}

Results of effects of exogenous application of proline on morphological attributes of okra genotypes under heat stress are given in Table 1. Foliar application of proline (P) and genotypes (C) significantly affected all of the okra's morphological properties. The $\mathrm{P} \times \mathrm{C}$ interaction effect was significant for all variables, except shoot and root dry weight. Proline significantly improves the shoot length of genotypes, increasing by $32.7 \%, 21.2 \%, 21 \%$, and $38.2 \%$ in $\mathrm{C} 1, \mathrm{C} 2, \mathrm{C} 3$, and $\mathrm{C} 4$, respectively, compared with their respective controls. Additionally, comparing results of proline (P1CX) and non-proline application (P0CX) on the genotypes, it was evidenced that exogenous application of proline increases the root 
length by $17.3 \%, 23.7 \%, 29 \%$, and $58.9 \%$, in $\mathrm{C} 1, \mathrm{C} 2, \mathrm{C} 3$, and C4, respectively. Furthermore, shoot fresh weights of $\mathrm{C} 1, \mathrm{C} 2, \mathrm{C} 3$, and $\mathrm{C} 4$ under the influence of proline increased by $63.8 \%$, $71.7 \%, 48.5 \%$, and $85.7 \%$, respectively. On the other hand, only root fresh weight decreased in all genotypes after proline application by $23.1 \%, 20 \%, 266.7 \%$, and $280.8 \%(C 1, C 2, C 3$, C4). The proline application significantly affected the shoot dry weight, as there were increases of $116.7 \%, 77.8 \%, 83.3 \%$, and $50 \%$ in $\mathrm{C} 1, \mathrm{C} 2, \mathrm{C} 3$, and $\mathrm{C} 4$, respectively. Root dry weights were enhanced by $50 \%, 100 \%, 100 \%$, and $100 \%$ and the number of leaves per plant were increased by $52.9 \%, 123.6 \%, 82.5 \%$, and $62.2 \%$ in $\mathrm{C} 1, \mathrm{C} 2, \mathrm{C} 3$, and C4, respectively, after exogenous application of proline.

Table 1. Effect of exogenous application of proline on morphological attributes of okra genotypes under heat stress.

\begin{tabular}{|c|c|c|c|c|c|c|c|}
\hline Effect & $\begin{array}{l}\text { Shoot Length } \\
\text { (cm) }\end{array}$ & $\begin{array}{l}\text { Root Length } \\
\text { (cm) }\end{array}$ & $\begin{array}{c}\text { Shoot Fresh } \\
\text { Weight } \\
\text { (g) }\end{array}$ & $\begin{array}{c}\text { Root Fresh } \\
\text { Weight } \\
\text { (g) }\end{array}$ & $\begin{array}{l}\text { Shoot Dry } \\
\text { Weight } \\
\text { (g) }\end{array}$ & $\begin{array}{l}\text { Root Dry } \\
\text { Weight } \\
\text { (g) }\end{array}$ & $\begin{array}{c}\text { No. of } \\
\text { Leaf/Plant }\end{array}$ \\
\hline \multicolumn{8}{|c|}{ Proline } \\
\hline $\mathrm{P} 0$ & $13.1 \mathrm{~b}$ & $7.4 \mathrm{~b}$ & $4.0 \mathrm{~b}$ & $0.60 \mathrm{a}$ & $0.6 \mathrm{~b}$ & $0.04 \mathrm{~b}$ & $5.6 \mathrm{~b}$ \\
\hline P1 & $16.8 \mathrm{a}$ & $9.6 \mathrm{a}$ & $6.7 \mathrm{a}$ & $0.30 \mathrm{~b}$ & $1.1 \mathrm{a}$ & $0.08 \mathrm{a}$ & $9.9 \mathrm{a}$ \\
\hline \multicolumn{8}{|c|}{ Cultivar } \\
\hline $\mathrm{C} 1$ & $17.8 \mathrm{a}$ & $11.3 \mathrm{a}$ & $6.2 \mathrm{~b}$ & $0.30 \mathrm{c}$ & $1.0 \mathrm{ab}$ & $0.07 \mathrm{a}$ & $10.8 \mathrm{a}$ \\
\hline $\mathrm{C} 2$ & $16.2 \mathrm{~b}$ & $8.5 \mathrm{~b}$ & $7.2 \mathrm{a}$ & $0.61 \mathrm{~b}$ & $1.2 \mathrm{a}$ & $0.06 \mathrm{ab}$ & $8.9 \mathrm{~b}$ \\
\hline $\mathrm{C} 3$ & $13.7 \mathrm{c}$ & $7.1 \mathrm{c}$ & $4.1 \mathrm{c}$ & $0.28 c$ & $0.8 \mathrm{~b}$ & $0.06 \mathrm{ab}$ & $5.6 \mathrm{c}$ \\
\hline $\mathrm{C} 4$ & $12.2 \mathrm{~d}$ & $7.3 \mathrm{c}$ & $4.0 \mathrm{c}$ & $0.63 \mathrm{a}$ & $0.5 \mathrm{c}$ & $0.04 \mathrm{~b}$ & $5.9 \mathrm{c}$ \\
\hline \multicolumn{8}{|c|}{ Interaction } \\
\hline P0 C1 & $15.3 \mathrm{c}$ & $10.4 \mathrm{~b}$ & $4.7 \mathrm{c}$ & 0.32 de & 0.6 & 0.06 & $8.5 \mathrm{~b}$ \\
\hline P0 C2 & $14.6 \mathrm{c}$ & $7.6 \mathrm{~d}$ & $5.3 \mathrm{c}$ & $0.66 \mathrm{~b}$ & 0.9 & 0.04 & $5.5 \mathrm{~cd}$ \\
\hline P0 C3 & $12.4 \mathrm{e}$ & $6.2 \mathrm{e}$ & $3.3 \mathrm{~d}$ & $0.44 \mathrm{~cd}$ & 0.6 & 0.04 & $4.0 \mathrm{~d}$ \\
\hline P0 C4 & $10.2 \mathrm{f}$ & $5.6 \mathrm{e}$ & $2.8 \mathrm{~d}$ & $0.99 \mathrm{a}$ & 0.3 & 0.03 & $4.5 \mathrm{~cd}$ \\
\hline P1 C1 & $20.3 \mathrm{a}$ & $12.2 \mathrm{a}$ & $7.7 \mathrm{~b}$ & 0.26 ef & 1.3 & 0.09 & $13.0 \mathrm{a}$ \\
\hline P1 C2 & $17.7 \mathrm{~b}$ & $9.4 \mathrm{bc}$ & $9.1 \mathrm{a}$ & $0.55 \mathrm{bc}$ & 1.6 & 0.08 & $12.3 \mathrm{a}$ \\
\hline P1 C3 & $15.0 \mathrm{c}$ & $8.0 \mathrm{~d}$ & $4.9 \mathrm{c}$ & $0.12 \mathrm{f}$ & 1.1 & 0.08 & $7.3 \mathrm{bc}$ \\
\hline P1 C4 & $14.1 \mathrm{~cd}$ & $8.9 \mathrm{~cd}$ & $5.2 \mathrm{c}$ & 0.26 ef & 0.6 & 0.06 & $7.3 \mathrm{bc}$ \\
\hline \multicolumn{8}{|c|}{ Significance } \\
\hline $\mathrm{P}$ & $* *$ & $* *$ & $* *$ & $* *$ & $* *$ & $* *$ & $* *$ \\
\hline $\mathrm{C}$ & $* *$ & $* *$ & $* *$ & $* *$ & $* *$ & $* *$ & $* *$ \\
\hline $\mathrm{P} \times \mathrm{C}$ & * & $*$ & $* *$ & $* *$ & NS & NS & * \\
\hline
\end{tabular}

Note: P0, Control (no proline application); P1, Proline application; $\mathrm{P} \times \mathrm{C}$, Proline and genotype interaction; $\mathrm{C} 1$, heat tolerant genotype 1; $\mathrm{C} 2$, heat tolerant genotype 2; C3, heat sensitive genotype 3; C4, heat sensitive genotype 4; $\mathrm{P}$, proline; $\mathrm{C}$, genotype. Different letters represent significant differences at $p<0.05$ probability level. * significant at the 0.05 probability level; ** significant at the 0.01 probability level; NS, not significant.

\subsection{Physiological Attributes}

Leaf temperature was significantly lowered by the application of proline on okra under heat stress. All the genotypes significantly lowered their leaf temperature with respect to the control. The highest leaf temperature lowering was recorded in $\mathrm{C}_{2}$, followed by $\mathrm{C} 1, \mathrm{C} 3$, and C4. (Figure 1A). Proline application significantly increased the sub-stomatal $\mathrm{CO}_{2}$ (VPM) in both heat-tolerant and heat-sensitive okra genotypes. The interaction effect of genotype and proline was observed as non-significant (Figure 1B). Results showed that more sub-stomatal $\mathrm{CO}_{2}$ was found in heat-sensitive okra genotypes, as compared to heat-tolerant genotypes. Stomatal conductance to the water was significantly affected by proline application. The interaction between proline and genotype was observed as non-significant. Results showed that the highest stomatal conductance to water was recorded in heat-sensitive genotypes $\mathrm{C} 3$ and $\mathrm{C} 4$ under the control treatment compared to proline application. Heat-tolerant okra genotypes showed low water loss through stomata compared to sensitive okra genotypes (Figure 1C). Exogenous application of proline left a significant effect on the transpiration rate; similarly, all okra genotypes showed significantly variable response for transpiration rate. The interaction effect (Proline $\times$ Genotype) was 
observed as non-significant. The highest transpiration rate was recorded in the case of heat-sensitive okra genotypes $\mathrm{C} 4$ and $\mathrm{C} 3$ in their respective control as compared to proline application. Similarly, the heat-tolerant okra genotypes showed low transpiration rates, compared to their respective controls. Overall, the proline application in all okra genotypes decreased the transpiration rates compared with their respective controls (Figure 1D). Proline application enhanced the photosynthesis in all okra genotypes, as compared to the control. The interaction effect of genotype and proline was non-significant. C1 (tolerant genotype) and C3 (sensitive genotype) showed maximum photosynthesis, but these were both at par. The lowest photosynthesis rate was recorded in the case of $\mathrm{C} 4$ under both proline and control conditions (Figure 1E). Proline application had a significant positive effect on water use efficiency (WUE), and okra genotypes were also significantly different in terms of WUE. Figure 1F shows a high WUE with proline applications in heat-tolerant okra genotypes $\mathrm{C} 1$ and $\mathrm{C} 2$ compared with the heat-sensitive genotypes.
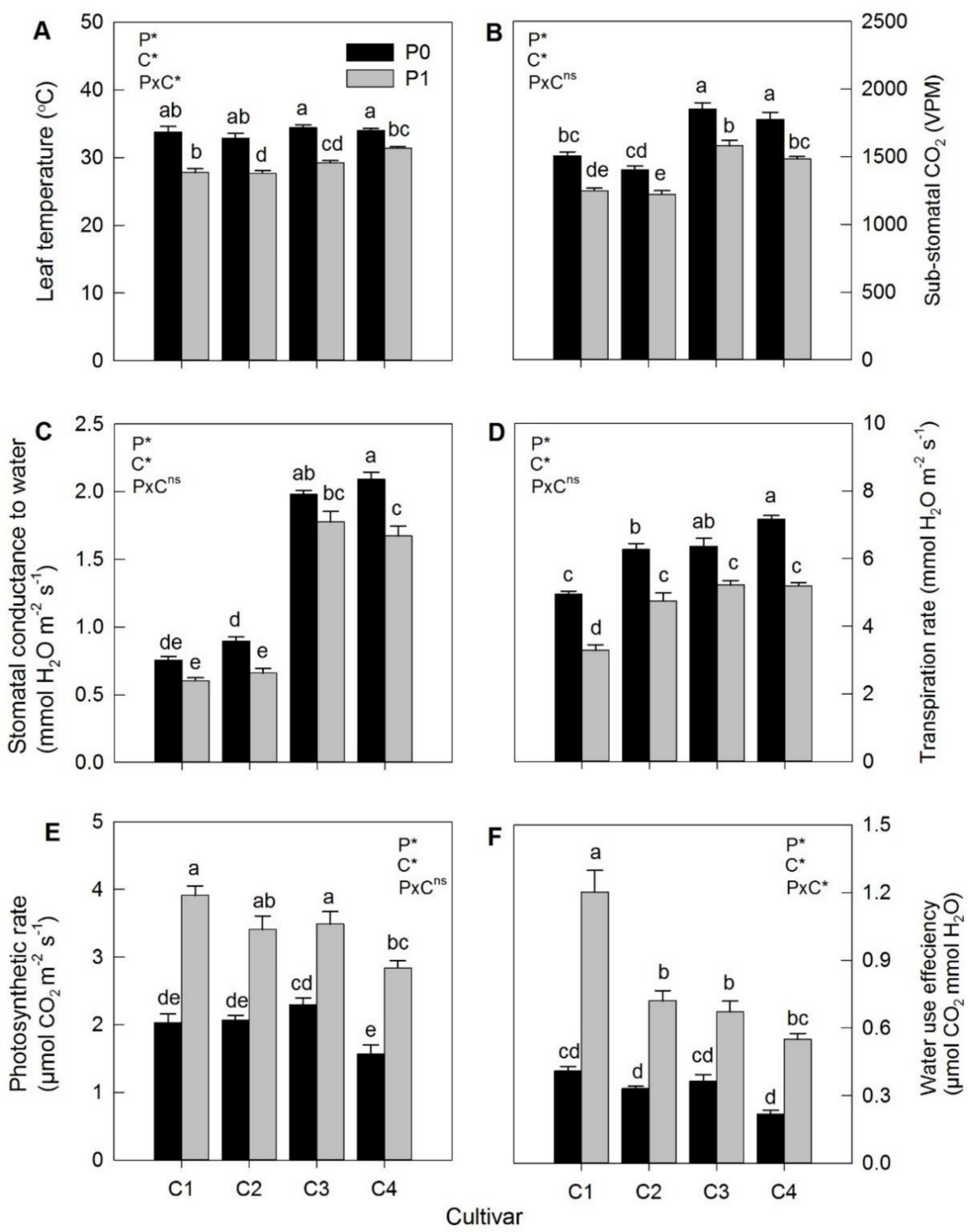

Figure 1. Effect of exogenous application of proline on physiological attributes of okra genotypes under heat stress. (A) Leaf temperature; (B) Sub-stomatal $\mathrm{CO}_{2}$; (C) Stomatal conductance to water; (D) Transpiration rate; (E) Photosynthetic rate; (F) Water use efficiency. Note: P0, Control (without proline application); P1, Proline application; $\mathrm{P} \times \mathrm{C}$, proline $\times$ genotype interaction; $\mathrm{C} 1$, heat tolerant genotype $1 ; \mathrm{C} 2$, heat tolerant genotype 2 ; $\mathrm{C} 3$, heat sensitive genotype 3 ; $\mathrm{C} 4$, heat sensitive genotype 4; $\mathrm{P}$, proline; $\mathrm{C}$, genotype. $\mathrm{P}^{*}, \mathrm{C}^{*}, \mathrm{P} \times \mathrm{C}^{*}$ and $\mathrm{P} \times \mathrm{C}^{\text {ns }}$ showed the significance for each factor. Different letters are significantly different $(p<0.05)$. 


\subsection{Antioxidant Enzyme Activity}

The results for superoxide dismutase (SOD) showed that proline application significantly enhanced its activity, and the genotype and treatment interaction effect was also significant (Figure 2A). C2 showed the highest SOD concentration and was at par with $\mathrm{C} 1$. In the heat-sensitive genotype, $\mathrm{C} 3$ showed a high SOD concentration compared to C4. Overall proline application enhanced the SOD concentration in both heat-tolerant and heat-sensitive okra genotypes as compared to their respective controls. Peroxidase (POD) concentration was significantly enhanced by proline application and okra genotypes behave differently (Figure 2B). Interaction of proline and genotype was observed as significant. Results showed that the highest POD concentration was recorded in heat-tolerant genotypes $\mathrm{C} 1$ and $\mathrm{C} 2$ under proline application as compared to their control. Okra genotypes that were heat-sensitive produced low POD compared to tolerant genotype under both with proline application and in the control treatment. Proline application significantly enhanced the catalase (CAT) concentration in heat-tolerant as well as heat-sensitive okra genotypes (Figure 2C). Results showed that the highest CAT concentration was obtained in heat-tolerant okra genotypes, but $\mathrm{C} 1$ produced slightly more concentration than $\mathrm{C} 2$. C3 and C4 followed these, but these heat-sensitive genotypes were mutually at par. All heat-tolerant and heat-sensitive genotypes produced relatively higher CAT concentrations with proline application than their respective control treatments.

\subsection{Water Relations}

There was a significant difference between the proline treatment and the control in all heat-tolerant and -sensitive okra genotypes for osmotic potential (Figure 3A). On the other hand, the interaction effect of genotype and proline application was observed as non-significant. Results for osmotic potential depicted the highest osmotic potential in $\mathrm{C} 1$, which was followed by $\mathrm{C} 2, \mathrm{C} 3$, and C4, which were statistically different with proline application, as compared with respective control treatments. Overall, the proline application enhanced osmotic potential in heat-tolerant and heat-sensitive okra genotypes. However, the interaction effect of genotype and proline application was observed as significant. The results also indicated that proline application significantly enhanced the water potential of okra genotypes (Figure 3B). Overall, the proline application enhanced the water potential in both heat-tolerant and heat-sensitive okra genotypes as compared with respective control treatments. Exogenous application of proline significantly affected the turgor potential of all the okra genotypes (Figure 3C). The interaction effect (proline $\times$ genotype) was observed as significant. It was also evidenced that the heat-tolerant okra genotypes $\mathrm{C} 1$ and $\mathrm{C} 2$ had the highest turgor potential under proline application, as compared with the respective control treatment. Overall, proline application in all okra genotypes increased the turgor potential with respect to their control. Results for relative water contents (RWC) depicted that the highest relative values were recorded in $\mathrm{C} 1$, which was followed by $\mathrm{C} 2$, respectively. $\mathrm{C} 3$ and $\mathrm{C} 4$ were statistically on par with each other under proline application. Overall, proline application enhanced RWC in heat-tolerant and sensitive genotypes as compared with respective control treatments (Figure 3D). 

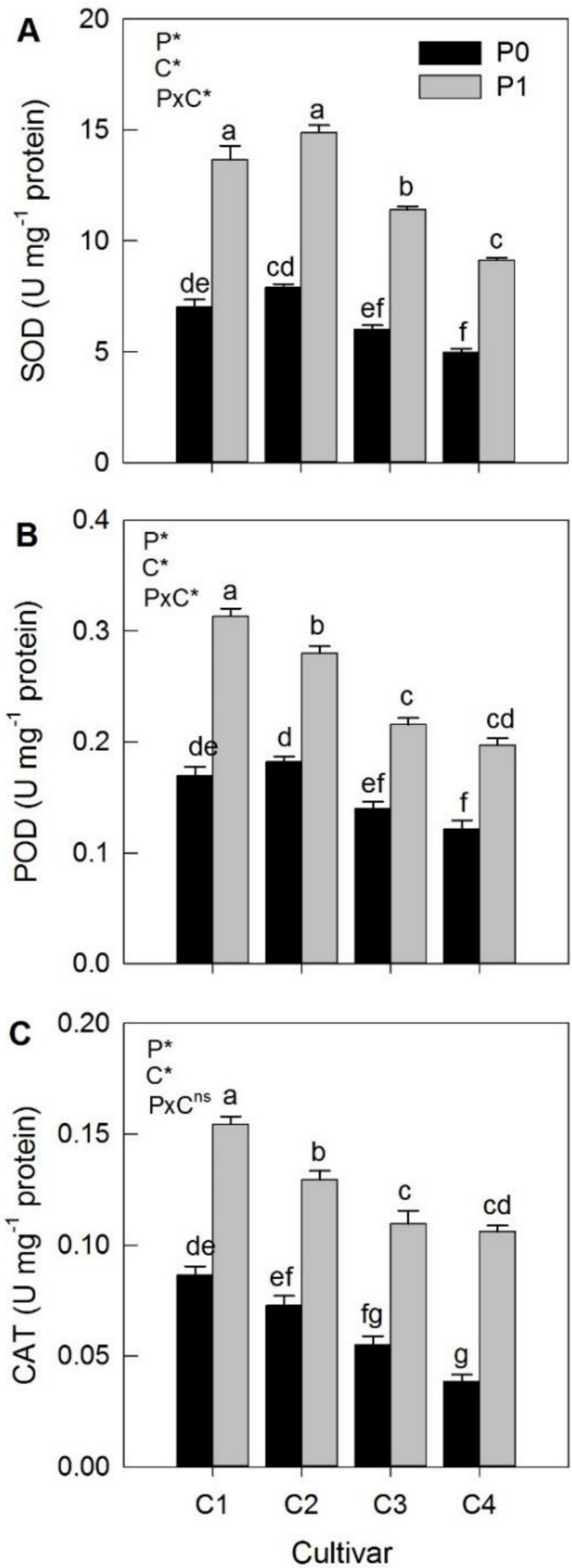

Figure 2. Effect of exogenous application of proline on the enzymatic activity of okra genotypes under heat stress. (A) Superoxide dismutase (SOD); (B) Peroxidase (POD); (C) Catalase (CAT). Note: P0, Control (without proline application); $\mathrm{P} 1$, Proline application; $\mathrm{P} \times \mathrm{C}$, proline $\times$ genotype interaction; $\mathrm{C} 1$, heat tolerant genotype $1 ; \mathrm{C} 2$, heat tolerant genotype 2; $\mathrm{C} 3$, heat sensitive genotype 3; $\mathrm{C} 4$, heat sensitive genotype 4; $\mathrm{P}$, proline; $\mathrm{C}$, genotype. $\mathrm{P}^{*}, \mathrm{C}^{*}, \mathrm{P} \times \mathrm{C}^{*}$ and $\mathrm{P} \times \mathrm{C}^{\text {ns }}$ showed the significance for each factor. Different letters are significantly different $(p<0.05)$. 

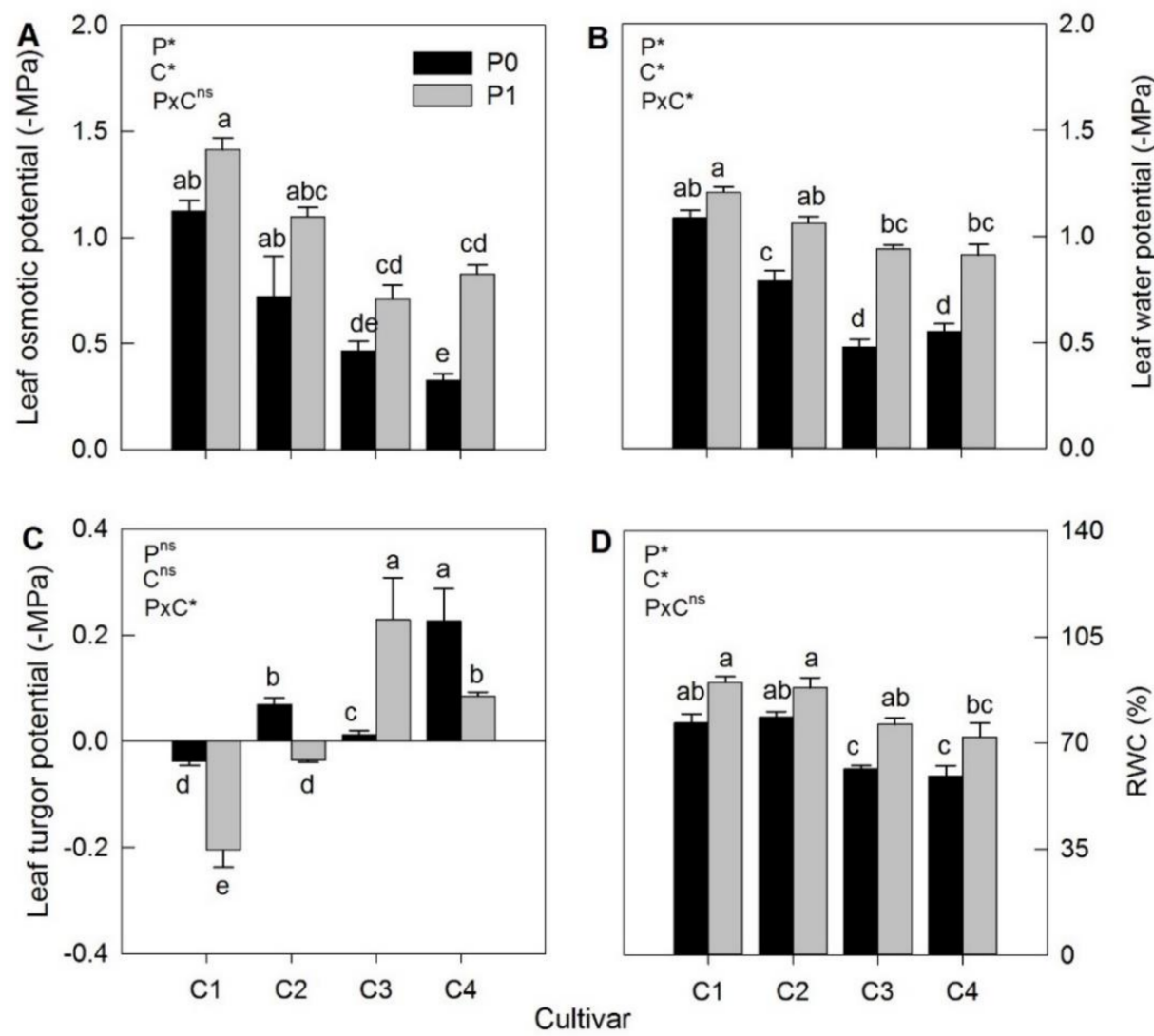

Figure 3. Effect of exogenous application of proline on water-related attributes of okra genotypes under heat stress. (A) Leaf osmotic potential; (B) Leaf water potential; (C) Leaf turgor potential; (D) Relative water content (RWC). Note: P0, Control (without proline application); P1, Proline application; $\mathrm{P} \times \mathrm{C}$, proline $\times$ genotype interaction; $\mathrm{C} 1$, heat tolerant genotype $1 ; \mathrm{C} 2$, heat tolerant genotype 2; $\mathrm{C} 3$, heat sensitive genotype 3 ; $\mathrm{C} 4$, heat sensitive genotype 4 ; $\mathrm{P}$, proline; $\mathrm{C}$, genotype. RWC, Relative water content. $\mathrm{P}^{*}, \mathrm{C}^{*}, \mathrm{P}^{\mathrm{ns}}, \mathrm{C}^{\mathrm{ns}}, \mathrm{P} \times \mathrm{C}^{*}$ and $\mathrm{P} \times \mathrm{C}^{\text {ns }}$ showed the significance for each factor. Different letters are significantly different $(p<0.05)$.

\subsection{Biochemical Attributes}

Exogenous application of proline significantly increased the leaf proline content of okra genotypes (Figure 4A). C1 and C2 had the highest proline content, followed by sensitive genotypes $\mathrm{C} 3$ and $\mathrm{C} 4$. All of the study genotypes showed higher proline content, comparing proline application with the control, but the extent was relatively greater in heat-tolerant genotypes than the heat-sensitive okra genotypes. The proline application significantly increased the glycinebetaine (GB) content of both heat-tolerant and -sensitive okra genotypes compared to the control (Figure 4B). The interaction effect of genotype and proline was significant. The highest GB content was produced in C2 compared to control, while the lowest GB content was recorded in C4 as compared to its control. Regarding the chlorophyll content, the results depicted that the highest chlorophyll content was recorded in $\mathrm{C} 1$ and was statistically at par with $\mathrm{C} 2$ under proline application, which were statistically different from the control treatment (Figure 4C). Heat-sensitive genotypes $\mathrm{C} 3$ and $\mathrm{C} 4$ lagged in terms of chlorophyll content in the heat-tolerant okra genotypes. Overall, the proline application enhanced chlorophyll production in heat-tolerant and sensitive genotypes as compared with the control treatment. The exogenous application of proline significantly increased the total free amino acid content of both heat-tolerant and sensitive genotypes as compared with the control treatment (Figure 4D). The interaction effect of genotype and proline was significant. The highest total free amino acid content was produced in $\mathrm{C} 1$ compared with the control treatment, while the lowest was recorded in C4. 

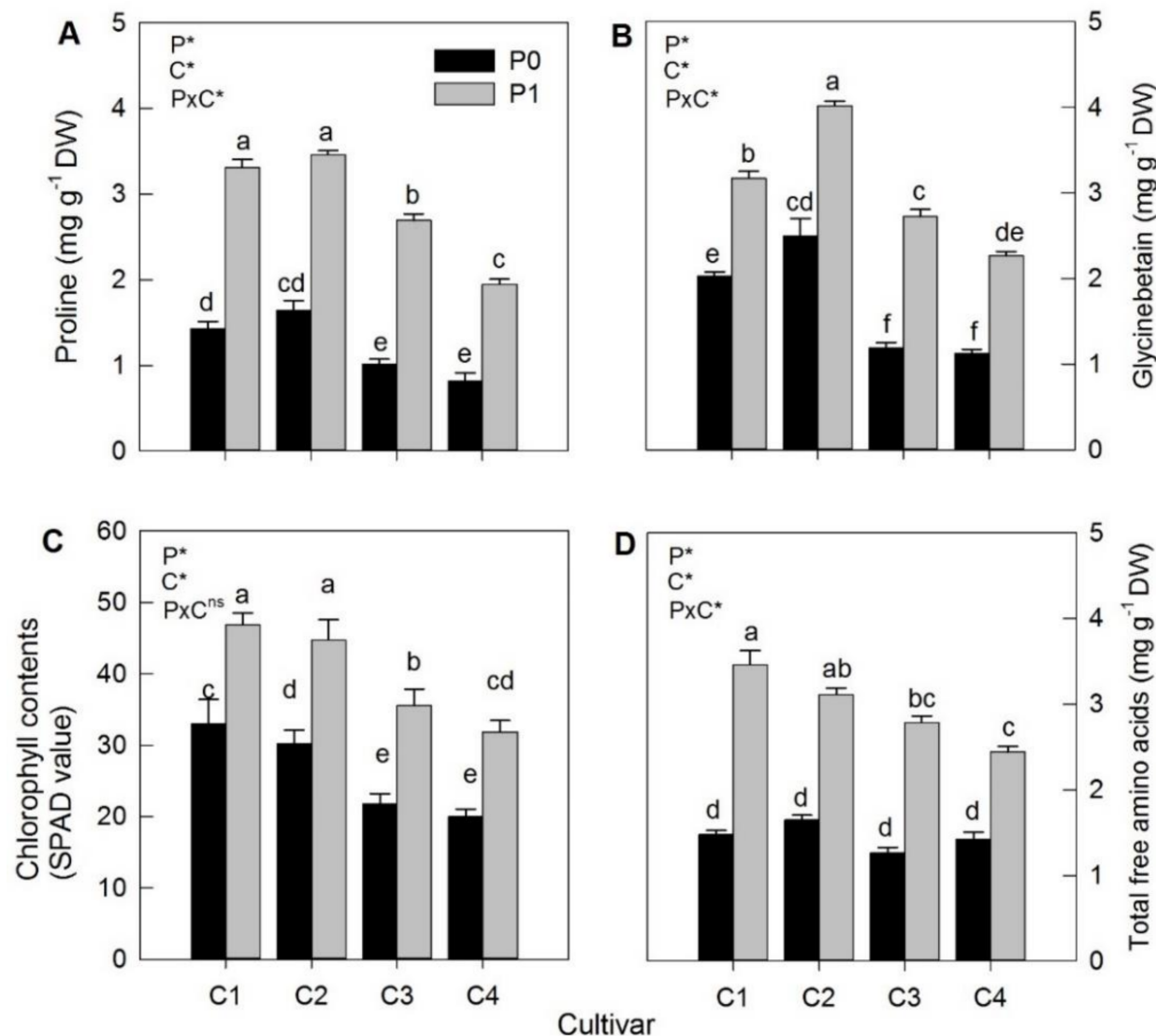

Figure 4. Effect of exogenous application of proline on biochemical attributes of okra genotypes under heat stress. (A) Proline; (B) Glycinebetain; (C) Chlorophyll contents; (D) Total free amino acids. Note: P0, Control (without proline application); P1, Proline application; $\mathrm{P} \times \mathrm{C}$, proline $\times$ genotype interaction; $\mathrm{C} 1$, heat tolerant genotype $1 ; \mathrm{C} 2$, heat tolerant genotype $2 ; \mathrm{C} 3$, heat sensitive genotype 3; $C 4$, heat sensitive genotype 4; $\mathrm{P}$, proline; $\mathrm{C}$, genotype. $\mathrm{P}^{*}, \mathrm{C}^{*}, \mathrm{P} \times \mathrm{C}^{*}$ and $\mathrm{P} \times \mathrm{C}^{\mathrm{ns}}$ showed the significance for each factor. Different letters are significantly different $(p<0.05)$.

\subsection{Inter-Trait Relationship}

Leaf proline content affected several other indices. Proline in the okra leaf had a linear negative relation $\left(R^{2}=0.6841\right)$ with sub-stomatal $\mathrm{CO}_{2}$ (Figure $5 \mathrm{~A}$ ). However, leaf proline content showed positive linear relations with the photosynthetic rate and the Soil Plant Analysis Development (SPAD) value (Figure 5B,C). Similarly, SOD, POD, and CAT activities were directly related to proline content in the okra leaf (Figure 5D-F). Leaf proline had a positive linear relation with leaf osmotic potential, water potential, and relative water content (Figure 5G-I). Overall, the leaf proline content improved the biochemical and water-related indices in the okra leaf.

The correlation analysis of various indices revealed that most of these were correlated with each other. Leaf temperature was positively correlated with gaseous exchange (GS), $\mathrm{Tr}$, and TP, but negatively correlated with SPAD value, Pn, WUE, proline (Pro), SOD, POD, CAT activities, total free amino acids (TFAA), and water relation parameters ( $\Psi \mathrm{s}, \Psi \mathrm{p}$, and RWC). Similarly, the SPAD value was positively correlated with all indices mentioned above, except GS, Tr, and TP (Table 2). The Pn showed the same correlation as was observed for the SPAD value. The GS showed a positive and significant correlation with water relation parameters. The Tr was significantly and negatively correlated with WUE, Pro, SOD, POD, and CAT activities, TFAA, and water relation parameters, except for TP. WUE and proline content showed a positive and significant correlation with enzyme activities, TFAA, and water relation parameters, except for $\Psi$ p. Enzyme activities were positively and significantly correlated with TFAA and water relations indices (Table 2). The TFAA was only significantly correlated to the WP and RWC of okra leaves. 

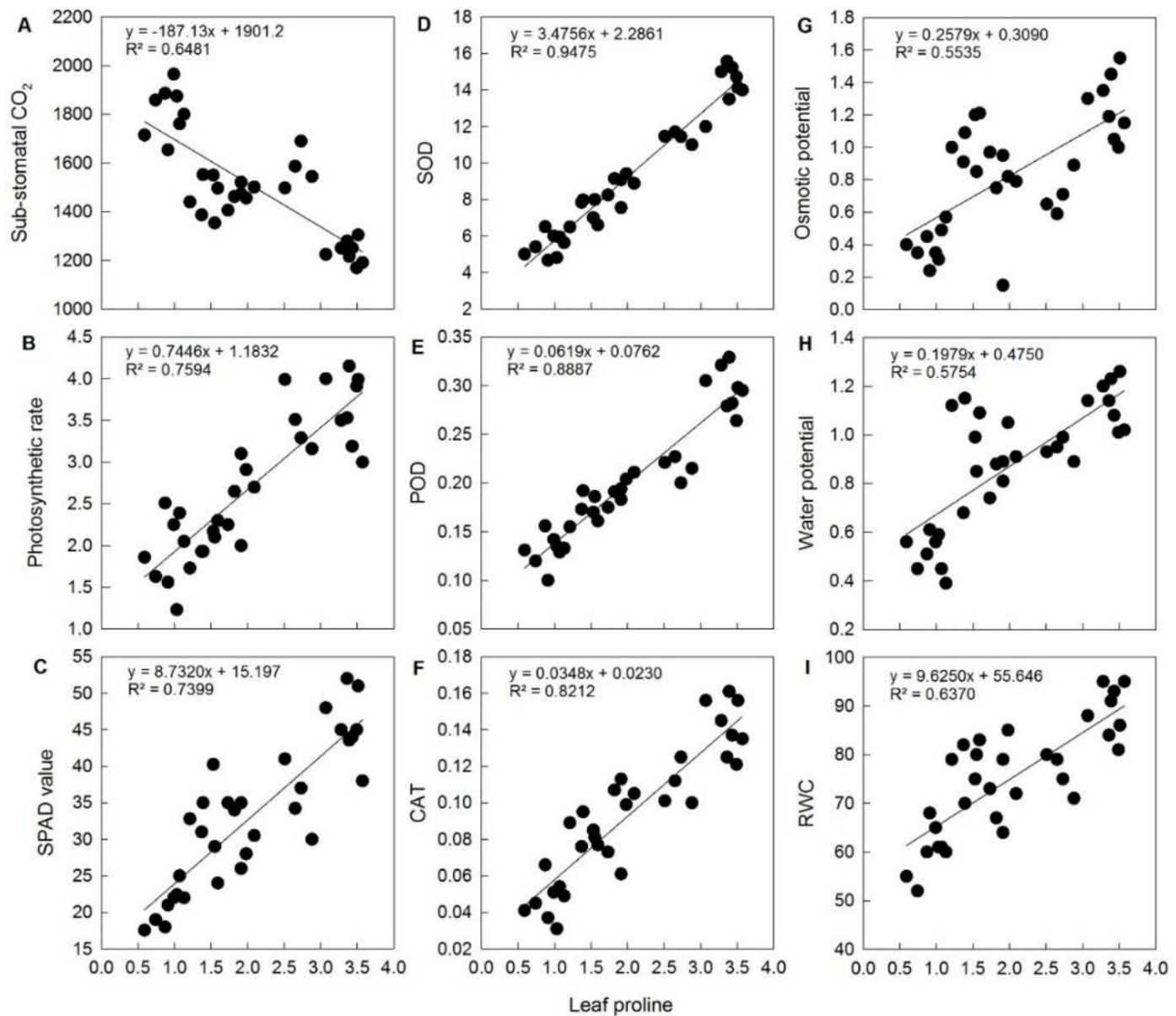

Figure 5. Effect of exogenous application of proline on inter-trait relationships of okra genotypes under heat stress. Note: CAT, Catalase; POD, Peroxidase; SOD, Superoxide dismutase; RWC, Relative water content; SPAD value, Chlorophyll content. The explanation for subfigures (A-I) already done in theory.

Table 2. Correlation analysis among different attributes of okra genotypes after exogenous application of proline under heat stress. Correlation coefficients (above diagonal) and significance (bellow diagonal).

\begin{tabular}{|c|c|c|c|c|c|c|c|c|c|c|c|c|c|c|c|}
\hline Trait & LT & SPAD & Pn & GS & TR & WUE & Pro & SOD & POD & CAT & TFA & $\psi_{s}$ & $\psi_{w}$ & $\psi_{p}$ & RWC \\
\hline LT & 1 & -0.91 & -0.94 & 0.49 & 0.78 & -0.87 & -0.99 & -0.98 & -0.95 & -0.91 & -0.99 & -0.66 & -0.73 & 0.37 & -0.87 \\
\hline SPAD & $* *$ & 1 & 0.86 & -0.78 & -0.92 & 0.88 & 0.95 & 0.95 & 0.97 & 0.96 & 0.90 & 0.90 & 0.92 & -0.63 & 0.97 \\
\hline Pn & $* * *$ & $* *$ & 1 & 0.36 & -0.83 & 0.92 & 0.93 & 0.92 & 0.92 & 0.93 & 0.95 & 0.65 & 0.68 & -0.26 & 0.74 \\
\hline GS & NS & * & NS & 1 & 0.70 & -0.53 & -0.60 & -0.60 & -0.68 & -0.63 & -0.46 & -0.88 & -0.80 & 0.76 & -0.89 \\
\hline TR & $*$ & $* *$ & $*$ & * & 1 & -0.92 & -0.82 & -0.80 & -0.90 & -0.95 & -0.82 & -0.95 & -0.91 & 0.73 & -0.85 \\
\hline WUE & $* *$ & $* *$ & $* *$ & NS & $* *$ & 1 & 0.87 & 0.85 & 0.94 & 0.92 & 0.91 & 0.80 & 0.76 & -0.64 & 0.78 \\
\hline Pro & $* * *$ & $* * *$ & $* * *$ & NS & * & $* *$ & 1 & 1 & 0.97 & 0.93 & 0.96 & 0.74 & 0.78 & -0.46 & 0.89 \\
\hline SOD & $* * *$ & $* * *$ & $* *$ & NS & * & $* *$ & $* * *$ & 1 & 0.97 & 0.92 & 0.95 & 0.73 & 0.76 & -0.47 & -0.88 \\
\hline POD & $* * *$ & $* * *$ & $* *$ & $*$ & $* *$ & $* * *$ & $* * *$ & $* * *$ & 1 & 0.96 & 0.95 & 0.83 & 0.82 & -0.02 & -0.92 \\
\hline CAT & $* *$ & $* * *$ & $* * *$ & * & $* * *$ & $* *$ & $* * *$ & $* * *$ & $* * *$ & 1 & 0.93 & 0.87 & 0.88 & -0.59 & 0.87 \\
\hline TFA & $* * *$ & $* *$ & $* * *$ & NS & * & $* *$ & $* * *$ & $* * *$ & $* * *$ & $* * *$ & 1 & 0.69 & 0.75 & 0.26 & 0.80 \\
\hline$\psi_{s}$ & * & $* *$ & * & $* * *$ & $* * *$ & * & * & * & * & $* *$ & * & 1 & 0.95 & -0.81 & 0.90 \\
\hline$\psi_{w}$ & * & $* *$ & * & * & $* *$ & * & * & * & * & $* *$ & * & $* *$ & 1 & -0.58 & 0.90 \\
\hline$\psi_{p}$ & NS & * & NS & * & * & * & NS & NS & NS & $* *$ & NS & $*$ & NS & 1 & -0.65 \\
\hline RWC & $*$ & $* *$ & $*$ & $* *$ & $* * *$ & * & $* *$ & $* *$ & $* *$ & $* *$ & * & $* *$ & $* *$ & $*$ & 1 \\
\hline
\end{tabular}

Relative water content, RWC; Turgor potential, $\psi_{p}$; Water potential, $\psi_{w}$; Osmotic potential, $\psi_{s}$; Total free amino acids, TFA; Catalase, CAT; Peroxidase, POD; Superoxide dismutase, SOD; Proline, Pro; Water use efficiency, WUE; Transpiration rate, TR; gaseous exchange, GS; Photosynthetic rate, Pn; Chlorophyll content, SPAD; Leaf temperature, LT. * ** and ${ }^{* * *}$ represent significance at $0.05,0.01$ and 0.001 , respectively. NS, not significant. 


\section{Discussion}

Several abiotic stresses affect plant growth and development, including heat stress, one of the major and basic stresses. This effect is sometimes so severe that plants cannot withstand it, leading to plant death [11]. Exogenous application of organic compounds increasing a plant's ability to tolerate heat stress is a very recent focus in agriculture. In a study conducted on sugarcane, the author found that exogenously applied GB (20 mM) and proline $(20 \mathrm{mM})$ improved various physiological processes and anatomical features in heat stressed plants [35]. Different organic compounds are used in stress tolerance in plants and reduce the adverse effect of stress, and proline has promising effects [36]. In plants, proline is involved to numerous environmental stresses and different developmental processes [37]. The accumulation of proline in response to different stresses is a well-established fact, and different roles for proline as an osmolyte, as an energy source or as a reactive oxygen species scavenger, have been proposed [38]. In the current study, exogenous application of proline played a vital role in improving morphological, physiological, and biochemical functions in okra genotypes. A similar case was reported in a study conducted on wheat under copper stress $[39,40]$ The number of leaves per plant was higher in heat-tolerant genotypes, as compared to heat-sensitive genotypes, because heat stress-tolerant okra genotypes retained their leaves and accumulated high proline in the leaf, while most of the leaves in heat-sensitive okra genotypes dropped their leaves, as discussed in the Results section (Figure 4). Shoot fresh weight was relatively high in heat-tolerant okra genotypes, because, under stress, they carry on their activities such as photosynthesis and then transfer these photosynthetic products to the roots and shoots. Low water loss was also a reason for high shoot fresh weights, while sensitive genotypes could not withstand heat stress and decreased in fresh weight. The same results were obtained [40]. The reason behind this was that the proline application increased the morphological parameters, and these findings have already been reported [38]. A high root and shoot weight (fresh and dry) is positively related to the number of leaves that contain the photosynthetic apparatus and that convert the solar energy into biomass [37]. Similarly, deep and long roots are helpful in the uptake of water and nutrients from the soil and of light from the sun, respectively [41]. In heat-tolerant genotypes, all of these characteristics helped in achieving high values in 131 morphological parameters that outperformed the heat-sensitive okra genotypes. Proline application was favorable to the production of biochemical substances, e.g., in proline content, total free amino acids, and carotenoid and chlorophyll content in the heat-tolerant okra genotypes. The same case was reported in a study conducted on wheat [40]. In heat-sensitive genotypes, these parameters were low because, upon exposure to heat stress, sensitive genotypes lost more leaves, more fresh and dry weight, and more water, which affected the above-mentioned parameters. Heat directly affects photosynthetic and metabolic activities and reduces efficiency, which reduces photosynthetic products and their conversion to amino acids and protein [38]. Proline content in heat-tolerant genotypes helped them to cope with high temperatures. Free amino acid content was also positively correlated with chlorophyll. Chlorophyll is an important pigment in plant leaves and is an essential part of the photosystem and the light-absorbing system [42]. More chlorophyll is directly related to a higher number of leaves. Physiological functions of a plant are affected by heat stress. In the current study, the leaf temperature of sensitive genotypes was high, and they lost more water through transpiration, as compared to tolerant genotypes. Lower water content and high transpiration through stomata explain the low photosynthetic rate in the sensitive genotypes. These physiological functions might have positive effects on stomatal opening, a necessary prerequisite of enhanced evapotranspiration. The stimulation of evapotranspiration by heat stress was recently described by Zhang et al. [43]. The correlation between leaf temperature and photosynthesis was negative, which indicated that heated leaves impair photo-assimilation. This reduction in the photosynthetic rate under high-temperature stress might be due to decreased stomatal conductance, as observed in this study. Similarly, a higher $\mathrm{CO}_{2}$ assimilation rate in heat-tolerant cultivars as compared to heat-sensitive ones 
under high-temperature stress was observed in previous studies and was attributed to their efficient photosynthetic apparatus $[40,44]$. Heat stress in sensitive genotypes caused more stomatal conductance for both water and carbon dioxide, while the reduction in stomatal conduction was more intense in heat-tolerant genotypes with the application of proline at $2.5 \mathrm{mM}$. Heat stress causes a rapid loss of water from the plant surface, which results in tissue and organ dehydration and restricts growth in plants [45]. High temperature causes osmotic stress to plant tissues owing to reduced root hydraulic conductance and tissue water status [13]. Turgor potential, osmotic potential, and water potential were high in the heat-tolerant okra genotypes compared with sensitive okra genotypes. High values in the above-mentioned parameters resulted in a higher relative water content, and proline application decreased stomatal water loss. The relationship between leaf proline content and water relation indices were linearly related (Figure 5G-I). Collectively, they favored dry matter production under heat stress and increased water use efficiency in heat-tolerant genotypes. One of the mechanisms involved in acclimation seems to be an accumulation of compatible solutes, especially proline. Apart from its osmolyte functions, proline exhibits many other protective effects, including the maintenance of redox balance and radical scavenging $[33,46,47]$. Transfer of plants to an elevated temperature $\left(40{ }^{\circ} \mathrm{C}\right)$ represents fast, acute stress. In our study, we found a decrease in leaf water potential in heat-stressed sensitive genotypes. This decrease was postponed in the heat-tolerant okra genotypes, which might indicate their enhanced stress tolerance. Enzymatic activities under heat stress were higher in heat tolerant genotypes. The enhanced activity and concentration of superoxide dismutase, peroxidase, and catalase can help establish heat-tolerant okra genotypes under stress conditions, while sensitive genotypes might not be able to cope with the situation and thus decline in all critical processes.

\section{Conclusions}

Both heat-tolerant genotypes (C1 = VI051062 and C2 = VI060131) performed more efficiently with proline applications in terms of all morphological, physiological, biochemical, water-related, and enzymatic attributes as compared to their corresponding control treatments. Additionally, this study provides insight into the physiological and biochemical inductions that occur in response to an increased genetic potential of plants and the exogenous application of proline, which help the plants to cope with the deleterious effects of heat stress. Heat tolerant genotypes can be used in breeding programs.

Author Contributions: Conceptualization, R.H., C.M.A., and M.R.S.; Data curation, R.H., S.R., M.B., and M.A.; Formal analysis, R.H., S.R., M.A., and M.B.; Investigation, R.H., M.R.S., A.M., and M.N.; Methodology, R.H., M.R.S., and M.N.; Resources, C.M.A., R.H., F.M.-P., and M.R.S.; Software, R.H., S.R., and M.B.; Supervision. R.H., M.R.S., S.F., and C.M.A.; Validation, M.R.S., S.A. (Sunny Ahmar) F.M.-P., S.F., M.N., and T.M.; Visualization, A.M., S.A. (Saif Ali) and R.H.; Writing-original draft, R.H., S.R., and M.R.S.; Writing-review and editing, R.H., F.M.-P., M.N., M.R.S., S.A. (Sunny Ahmar), and T.M. All authors have read and agreed to the published version of the manuscript.

Funding: The authors are grateful to the Australian Center for International Agricultural Research (ACIAR) for financial support, and to the World Vegetable Centre (AVRDC) for providing germplasm. F.M.-P. and S.A. thank the Chilean National Fund for Scientific and Technological Development (FONDECYT) Grant No. 1201973.

Data Availability Statement: Not applicable.

Conflicts of Interest: The authors declare that there is no conflict of interest.

\section{References}

1. Niu, Y.; Xiang, Y. An overview of biomembrane functions in plant responses to high-temperature stress. Front. Plant Sci. 2018, 9 , 1-18. [CrossRef] [PubMed]

2. Nazir, A.; Shaheen, M.R.; Ayyub, C.M.; Hussain, R.; Sarwer, N.; Imran, M.; Aurangzaib, M.; Nawaz, M.; Ali Khan, M.F.; Jawad, Y.; et al. Exploring the better genetic options from indigenous material to cultivate tomato under high temperature regime. J. Appl. Bot. Food Qual. 2017, 90, 339-345. [CrossRef] 
3. Meehl, G.A.; Tebaldi, C. More intense, more frequent, and longer lasting heat waves in the 21st century. Science 2004, 305, 994-997. [CrossRef] [PubMed]

4. Folland, C.K.; Karl, T.R.; Christy, J.R.; Clarke, R.; Gruza, G.; Jouzel, J.; Mann, M.; Oerlermans, J.; Salinger, M.; Wang, S. Climate Change 2001: The Scientific Basis; Hought, J.T., Ed.; The Press Syndicate of the University of Cambridge: Cambridge, UK, 2001.

5. Pereira, A. Plant abiotic stress challenges from the changing environment. Front. Plant Sci. 2016, 7. [CrossRef]

6. Ruelland, E.; Zachowski, A. How plants sense temperature. Environ. Exp. Bot. 2010, 69, 225-232. [CrossRef]

7. Bita, C.E.; Gerats, T. Plant tolerance to high temperature in a changing environment: Scientific fundamentals and production of heat stress-tolerant crops. Front. Plant Sci. 2013, 4, 273. [CrossRef]

8. Madlung, A.; Comai, L. The effect of stress on genome regulation and structure. Ann. Bot. 2004, 94, 481-495. [CrossRef]

9. Lobell, D.B.; Asner, G.P. Climate and management contributions to recent trends in U.S. agricultural yields. Science 2003, $299,1032$. [CrossRef]

10. Bray, E.A.; Bailey-Serres, J.; Weretilnyk, E. Responses to abiotic stresses. In Biochemistry and Molecular Biology of Plants; John Wiley \& Sons: Hoboken, NJ, USA, 2000; Volume 139, pp. 1158-1203. [CrossRef]

11. Wahid, A.; Close, T.J. Expression of dehydrins under heat stress and their relationship with water relations of sugarcane leaves. Biol. Plant. 2007, 51, 104-109. [CrossRef]

12. Bañon, S.; Fernandez, J.A.; Franco, J.A.; Torrecillas, A.; Alarcón, J.J.; Sánchez-Blanco, M.J. Effects of water stress and night temperature preconditioning on water relations and morphological and anatomical changes of Lotus creticus plants. Sci. Hortic. 2004, 101, 333-342. [CrossRef]

13. Wahid, A.; Gelani, S.; Ashraf, M.; Foolad, M.R. Heat tolerance in plants: An overview. Environ. Exp. Bot. 2007, 61, 199-223. [CrossRef]

14. Young, L.W.; Wilen, R.W.; Bonham-Smith, P.C. High temperature stress of Brassica napus during flowering reduces micro- and megagametophyte fertility, induces fruit abortion, and disrupts seed production. J. Exp. Bot. 2004, 55, 485-495. [CrossRef]

15. Tsukaguchi, T.; Kawamitsu, Y.; Takeda, H.; Suzuki, K.; Egawa, Y. Water status of flower buds and leaves as affected by high temperature in heat-tolerant and heat-sensitive cultivars of snap bean (Phaseolus vulgaris L.). Plant Prod. Sci. 2003, 6, 24-27. [CrossRef]

16. Xiong, F.S.; Mueller, E.C.; Day, T.A. Photosynthetic and respiratory acclimation and growth response of Antarctic vascular plants to contrasting temperature regimes. Am. J. Bot. 2000, 87, 700-710. [CrossRef]

17. Prasad, P.V.V.; Staggenborg, S.A.; Ristic, Z. Impacts of Drought and/or Heat Stress on Physiological, Developmental, Growth, and Yield Processes of Crop Plants. Adv. Agric. Syst. Model. 2015, 301-355. [CrossRef]

18. Sakamoto, A.; Murata, N. The role of glycinebetaine in the protection of plants from stress: Clues from transgenic plants. Plant Cell Environ. 2002, 25, 163-171. [CrossRef]

19. Sairam, R.K.; Tyagi, A. Physiology and molecular biology of salinity stress tolerance in plants. Curr. Sci. 2004, 86, 407-421.

20. Quan, R.; Shang, M.; Zhang, H.; Zhao, Y.; Zhang, J. Engineering of enhanced glycinebetaine synthesis improves drought tolerance in maize. Plant Biotechnol. J. 2004, 2, 477-486. [CrossRef] [PubMed]

21. Rachel, T.; Mellob, S.C.; Momessoc, P.; Pedroso, R.M. L-proline alleviates heat stress of tomato plants grown under protected environment. Sci. Hortic. 2020, 268, 1-7.

22. Wilfried, C. Proline as a measure of stress in tomato plants. Plant Sci. 2005, 168, 241-248.

23. Hamilton, E.W.; Heckathorn, S.A. Mitochondrial adaptations to NaCl. Complex I is protected by antioxidants and small heat shock proteins, whereas complex II is protected by proline and betaine. Plant Physiol. 2001, 126, 1266-1274. [CrossRef] [PubMed]

24. Chedlia, B.A.; Rouina, B.B.; Boukhriss, S.S.M.; Abdullah, F.B. Exogenous proline effects on photosynthetic performance and antioxidant defense system of young olive tree. J. Agric. Food Chem. 2010, 58, 4216-4222.

25. Shamsul, H.; Hayat, Q.; Alyemeni, M.N.; Wani, A.S.; Pichtel, J.; Ahmad, A. Role of proline under changing environments: A review. Plant Signal. Behav. 2012, 7, 1456-1466.

26. Hussain, R.; Ayyub, C.M.; Amjad, M.; Waraich, E.A.; Shaheen, M.R.; Mustafa, Z.; Shah, S.Z.H.; Shahid, A.; Haider, W.H.; Faiz, H.; et al. Evaluation of Heat Tolerance Potential of Okra Genotypes in Field Conditions at Different Sowing Dates. Transylv. Rev. 2016, XXIV, 3416-3427.

27. Hussain, R.; Ayyub, C.M.; Amjad, M.; Waraich, E.A. Determination of Best Proline Concentration for Alleviation of Temperature Stress Damages in Okra (Abelmoschus esculentus L. Moench). Sylwan 2016, 160, 170-190.

28. Munger, P.; Bleiholder, H.; Hack, H.; Hess, M.; Stauss, R.; Boom, V.D. Phenological growth stages of the cotton plant (Gossypium hirsutum L.): Codification and description according to the BBCH scale. J. Agron. Crop Sci. 1998, 180, 143-149. [CrossRef]

29. Giannopolitis, C.N.; Ries, S.K. Superoxide dismutase I. Occurrence in higher plants. Plant Physiol. 1977, 59, 309-314. [CrossRef]

30. Chance, B.; Maehly, A.C. Assay of catalase and peroxidase. Methods Enzymol. 1955, 2, 764-775.

31. Barrs, H.D.; Weatherley, P.E. A re-examination of the relative turgidity technique for estimating water deficits in leaves. Aust. J. Biol. Sci. 1962, 15, 413-428. [CrossRef]

32. Bates, L.S.; Waldron, R.P.; Teare, I.D. Rapid determination of free proline for water stress studies. Plant Soil 1973, 39, $205-207$. [CrossRef]

33. Grieve, C.M.; Grattan, S.R. Rapid assay for determination of water soluble quaternary ammonium compounds. Plant Soil 1983, 70, 303-307. [CrossRef] 
34. Rasheed, R.; Wahid, A.; Farooq, M.; Hussain, I.; Basra, S.M.A. Role of proline and glycinebetaine pretreatments in improving heat tolerance of sprouting sugarcane (Saccharum sp.) buds. Plant Growth Regul. 2011, 65, 35-45. [CrossRef]

35. Biology, A. Responses of Some Local/Exotic Accessions of lentil (Lens culinaris) decades. J. Agron. Crop Sci. 1993, $42,63-72$.

36. Hassan, M.U.; Chattha, M.U.; Khan, I.; Chattha, M.B.; Barbanti, L.; Aamer, M.; Iqbal, M.M.; Nawaz, M.; Mahmood, A.; Ali, A.; et al. Heat stress in cultivated plants: Nature, impact, mechanisms, and mitigation strategies-A review. Plant Biosyst. 2020, 211-234. [CrossRef]

37. Saradhi, P.P. Proline accumulates in plants exposed to UV radiation and protects them against UV induced peroxidation. Biochem. Biophys. Res. Commun. 1995, 209, 1-5. [CrossRef]

38. Schwachtje, J.; Whitcomb, S.J.; Firmino, A.A.P.; Zuther, E.; Hincha, D.K.; Kopka, J. Induced, imprinted, and primed responses to changing environments: Does metabolism store and process information? Front. Plant Sci. 2019, 10. [CrossRef]

39. Szabados, L.; Savouré, A. Proline: A multifunctional amino acid. Trends Plant Sci. 2010, 15, 89-97. [CrossRef]

40. Noreen, S.; Akhter, M.S.; Yaamin, T.; Arfan, M. The ameliorative effects of exogenously applied proline on physiological and biochemical parameters of wheat (Triticum aestivum L.) crop under copper stress condition. J. Plant Interac. 2018, 13, 221-230. [CrossRef]

41. Ayyaz, A.; Amir, M.; Umer, S.; Iqbal, M.; Bano, H.; Gul, H.S.; Noor, Y.; Kanwal, A.; Khalid, A.; Javed, M.; et al. Melatonin induced changes in photosynthetic efficiency as probed by OJIP associated with improved chromium stress tolerance in canola (Brassica napus L.). Heliyon 2020, 6. [CrossRef]

42. Ashraf, M.; Harris, P.J.C. Photosynthesis under stressful environments: An overview. Photosynthetica 2013, 51, 163-190. [CrossRef]

43. Lynch, J.P. Root phenotypes for improved nutrient capture: An underexploited opportunity for global agriculture. New Phytol. 2019, 223, 548-564. [CrossRef]

44. Sadura, I.; Pociecha, E.; Dziurka, M.; Oklestkova, J.; Novak, O.; Gruszka, D.; Janeczko, A. Mutations in the HvDWARF, HvCPD and HvBRI1 Genes-Involved in Brassinosteroid Biosynthesis/Signalling: Altered Photosynthetic Efficiency, Hormonal Homeostasis and Tolerance to High/Low Temperatures in Barley. J. Plant Growth Regul. 2019, 38, 1062-1081. [CrossRef]

45. Shahid, M.A.; Balal, R.M.; Pervez, M.A.; Abbas, T.; Aqeel, M.A.; Javaid, M.M.; Garcia-Sanchez, F. Exogenous proline and proline-enriched Lolium perenne leaf extract protects against phytotoxic effects of nickel and salinity in Pisum sativum by altering polyamine metabolism in leaves. Turk. J. Bot. 2014, 38, 914-926. [CrossRef]

46. Zhang, X.; Wollenweber, B.; Jiang, D.; Liu, F.; Zhao, J. Water deficits and heat shock effects on photosynthesis of a transgenic Arabidopsis thaliana constitutively expressing ABP9, a bZIP transcription factor. J. Exp. Bot. 2008, 59, 839-848. [CrossRef]

47. Ahmar, S.; Gill, R.A.; Jung, K.H.; Faheem, A.; Qasim, M.U.; Mubeen, M.; Zhou, W. Conventional and molecular techniques from simple breeding to speed breeding in crop plants: Recent advances and future outlook. Int. J. Mol. Sci. 2020, 21, 2590. [CrossRef] 